\title{
О РАБОТЕ IV МЕЖДУНАРОДНОГО КОНГРЕССА СРЕДНЕВЕКОВОЙ АРХЕОЛОГИИ ЕВРАЗИЙСКИХ СТЕПЕЙ, ПОСВЯЩЕННОГО 100-ЛЕТИЮ РОССИЙСКОЙ АКАДЕМИЧЕСКОЙ АРХЕОЛОГИИ
}

\author{
(C) 2019 г. А.Г. Ситдиков, Б.А. Базаров, А.Д. Гомбожапов, \\ Е.В. Нолев, П.В. Красильников
}

16-21 сентября 2019 г. в г. Улан-Удэ состоялся IV Международный конгресс средневековой археологии евразийских степей «Кочевые империи Евразии в свете археологических и междисциплинарных исследований», посвященный 100-летию российской академической археологии. Для участия в конгрессе было заявлено 229 докладов ученых из различных стран: России, Казахстана, Франции, Германии, Австрии, Великобритании, Канады, Швейцарии, Испании, Болгарии, Венгрии, Хорватии, Украины, Турции, Израиля, Индии, Кыргызстана, Китая, Японии и Монголии. В рамках Конгресса в Национальном музее Республики Бурятия прошло открытие выставки «Гунны. Империя степей» (Хунну. Тайны исчезнувших цивилизаций). В ходе Конгресса были продемонстрированы достижения современной археологии с безусловной опорой на предшествующий столетний опыт развития академической археологической науки и поставлены новые перспективные цели и задачи. Следующий Международный конгресс средневековой археологии евразийских степей пройдет в Казахстане в 2021 г. на базе Института археологии им. А.Х. Маргулана, в рамках празднования 30-летнего юбилея Института.

Ключевые слова: археология, международный конгресс, Евразия, кочевые империи, городская культура, междисциплинарные исследования

В 2019 г. в России отмечается 100-летие российской академической археологии. Ровно 100 лет назад декретом Народных Комиссаров 18 апреля 1919 г. была учреждена Российская Академия истории материальной культуры. Одним из значимых мероприятий в рамках празднования 100-летнего юбилея стал IV Международный конгресс средневековой археологии евразийских степей «Кочевые империи Евразии в свете археологических и междисциплинарных исследований», который прошел в г. Улан-Удэ на базе Института монголоведения, буддологии и тибетологии СО РАН с 16 по 21 сентября 2019 г. Традиция проведения научного мероприятия была заложена на Учредительном съезде Международ-

Работа выполнена в рамках государственного задания ИМБТ СО РАН по проекту № 0338-2016-0003 «Межкультурное взаимодействие, этнические и социальнополитические процессы в Центральной Азии», номер государственной регистрации № AAAA-A17-117021310264-4 
Ситдиков А.Г., Базаров Б.А., Гомбожапов А.Д., Нолев Е.В., Красильников П.В. О работе IV международного конгресса средневековой археологии евразийских степей...

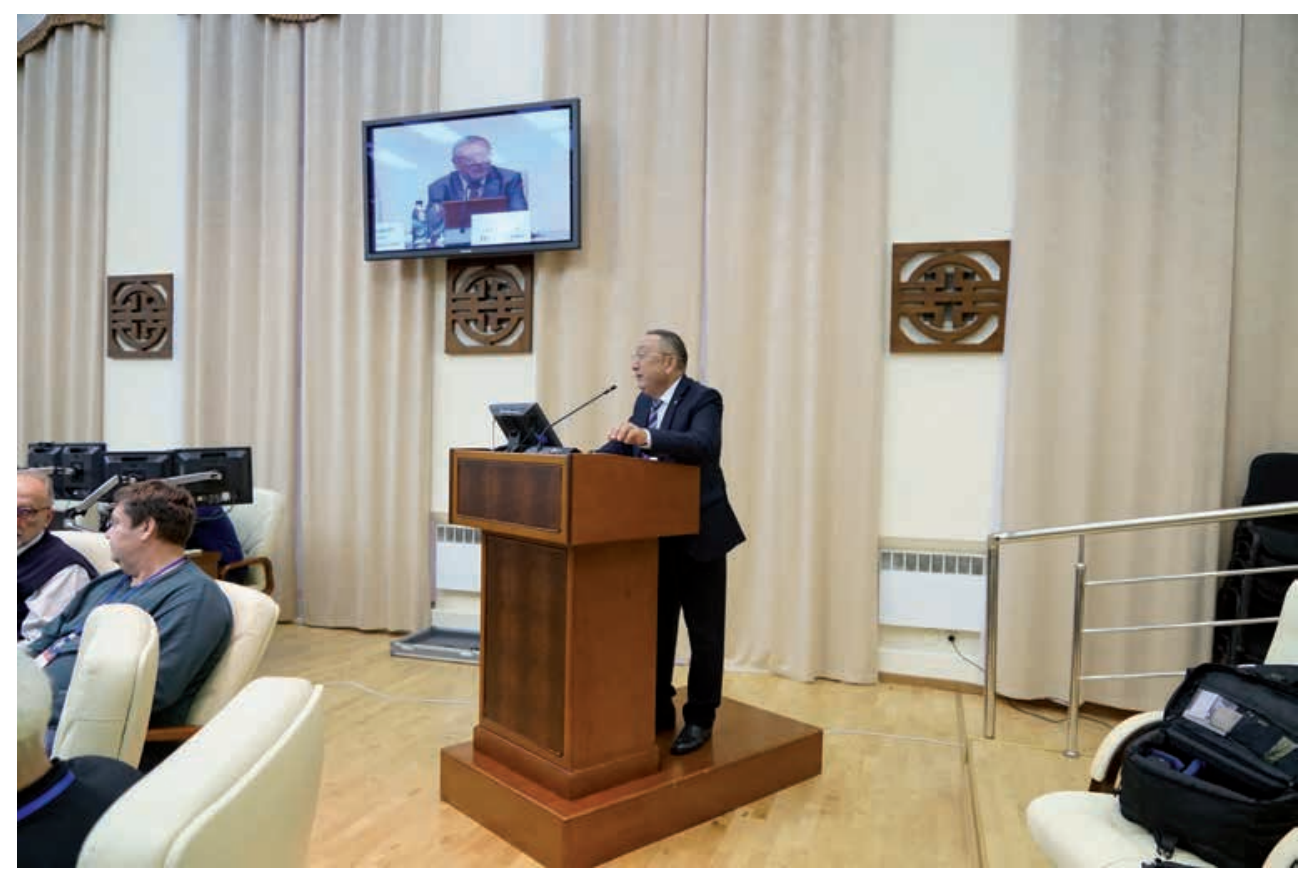

Рис. 1. Пленарное заседание (Дом правительства Республики Бурятия). Выступает с докладом директор Института археологии им. А.Х. Маргулана, академик НАН РК Б.А. Байтанаев

Fig. 1. Plenary session (House of the Government of Buryat Republic). Director of the A.Kh. Margulan Institute of Archaeology, academician of the National Academy of Sciences of the Republic of Kazakhstan B.A. Baytanaev makes a presentation

ного конгресса средневековой археологии евразийских степей в 2007 г. в Казани, где было принято решение о создании новой научной организационной структуры, объединяющей и координирующей усилия археологов в изучении истории народов степей Евразии и сопредельных территорий [Ситдиков и др., 2012, с. 233].

В числе организаторов IV Международного конгресса средневековой археологии евразийских степей «Кочевые империи Евразии в свете археологических и междисциплинарных исследований» Министерство науки и высшего образования Российской Федерации; Институт монголоведения, буддологии и тибетологии СО РАН; Институт истории, археологии и этнографии народов
Дальнего Востока ДВО РАН; Институт археологии им. А.Х. Халикова Академии наук Республики Татарстан; Казанский (Приволжский) федеральный университет; Институт археологии им. А.Х. Маргулана Республики Казахстан; Международный институт центральноазиатских исследований ЮНЕСКО; Международная ассоциация монголоведения; Институт истории и этнологии Академии наук Монголии; Институт археологии Академии наук Монголии; Министерство образования и науки Республики Бурятия; Министерство культуры Республики Бурятия; Национальный музей Республики Бурятия; Российское историческое общество; Фонд «История Отечества». IV Конгресс, как и предыдущий в г. Вла- 


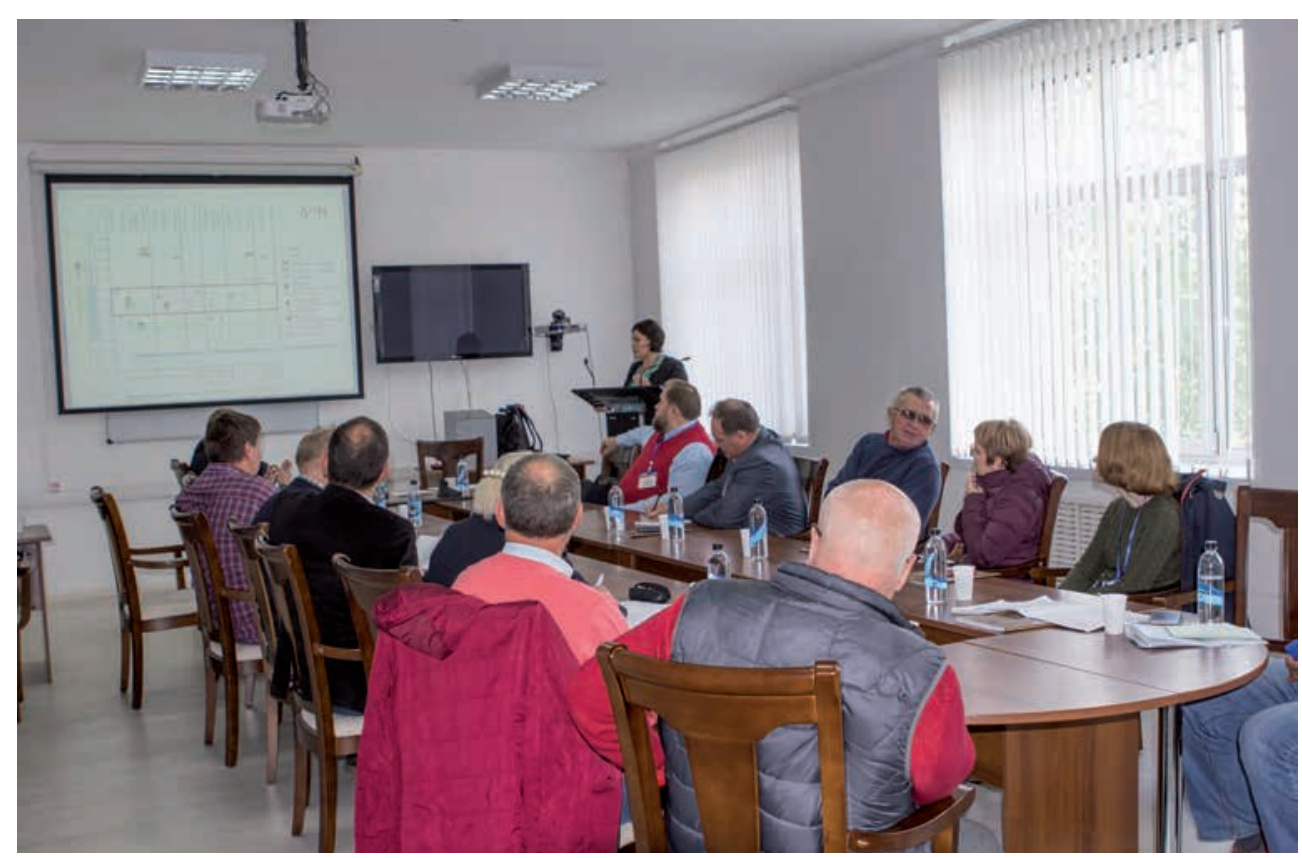

Рис. 2. Работа секйии № 4 Реконструкичия экономических, социально-политических прочессов в кочевых империях и на их перифериях. Выступает с докладом А.М. Хубанова (Геологический институт СО РАН)

Fig. 2. Work of Section no. 4 Reconstruction of economic, socio-political processes in nomadic empires and on their peripheries. A.M. Khubanova makes a presentation (Geological Institute of the Siberian Branch of the Russian Academy of Sciences)

дивостоке в 2017 г., был организован при поддержке мегагранта Правительства Российской Федерации в рамках реализации проекта ИМБТ СО РАН «Динамика народов и империй в истории Внутренней Азии».

В программу Конгресса вошли доклады ученых из России, Казахстана, Франции, Германии, Австрии, Великобритании, Канады, Швейцарии, Испании, Болгарии, Венгрии, Хорватии, Украины, Турции, Израиля, Индии, Кыргызстана, Китая, Японии и Монголии. В целом, на Конгресс было заявлено семь пленарных и 222 секционных доклада.

На пленарном заседании, состоявшемся в Доме Правительства Республики Бурятия, прозвучали приветственные слова директора Института монголоведения, буддологии и тибетологии СО РАН, научного руководителя Бурятского научного центра СО РАН, председателя Совета Отделения Российского исторического общества в г. Улан-Удэ, академика РАН Б.В. Базарова; декана высшей школы исторических наук и всемирного культурного наследия Института международных отношений Казанского федерального университета, директора Института археологии им. А.Х. Халикова Академии наук Республики Татарстан, членакорреспондента АН РТ А.Г. Ситдикова; директора Института истории и этнологии Академии наук Монголии, генерального секретаря Международной ассоциации монголоведения, академика AHM, Sc.D. Сампилдондова Чулууна; первого заместителя министра - председателя Комитета 
Ситдиков А.Г., Базаров Б.А., Гомбожапов А.Д., Нолев Е.В., Красильников П.В. О работе IV международного конгресса средневековой археологии евразийских степей...

по науке и профессиональному образованию Министерства образования и науки Республики Бурятия, д.п.н. Г.Н. Фомицкой; директора Национального музея Республики Бурятия, кандидата искусствоведения Т.А. Бороноевой.

После приветственных слов пленарное заседание продолжили научные доклады. Директор Института истории, археологии и этнографии народов Дальнего Востока ДВО РАН, научный руководитель лаборатории археологии, этнологии и антропологии ИМБТ СО РАН, член-корреспондент РАН Н.Н. Крадин представил предварительные итоги реализации мегапроекта «Динамика народов и империй в истории Внутренней Азии», проводимого с 2017 г. на базе ИМБТ СО РАН. С докладами выступили руководитель отдела Древней истории Института Всеобщей истории РАН, членкорреспондент РАН А.И. Иванчик, директор Музея антропологии и этнографии (Кунсткамера) РАН, членкорреспондент РАН А.В. Головнев, член-корреспондент АН РТ А.Г. Ситдиков, профессор Практической школы высших исследований П. Марсон, генеральный директор Института археологии им. А.Х. Маргулана, академик НАН РК Б.А. Байтанаев, доктор археологии из Археологического музея г. Варны В. Йотов.

В ходе работы Конгресса состоялись доклады на следующих секциях: 1. «Городская культура степной Евразии» (руководители секции: чл.-корр. РАН Н.Н. Крадин, д.и.н. И.Л. Измайлов), 2. «Погребальные и ритуально-культовые памятники кочевников Евразии» (руководите-

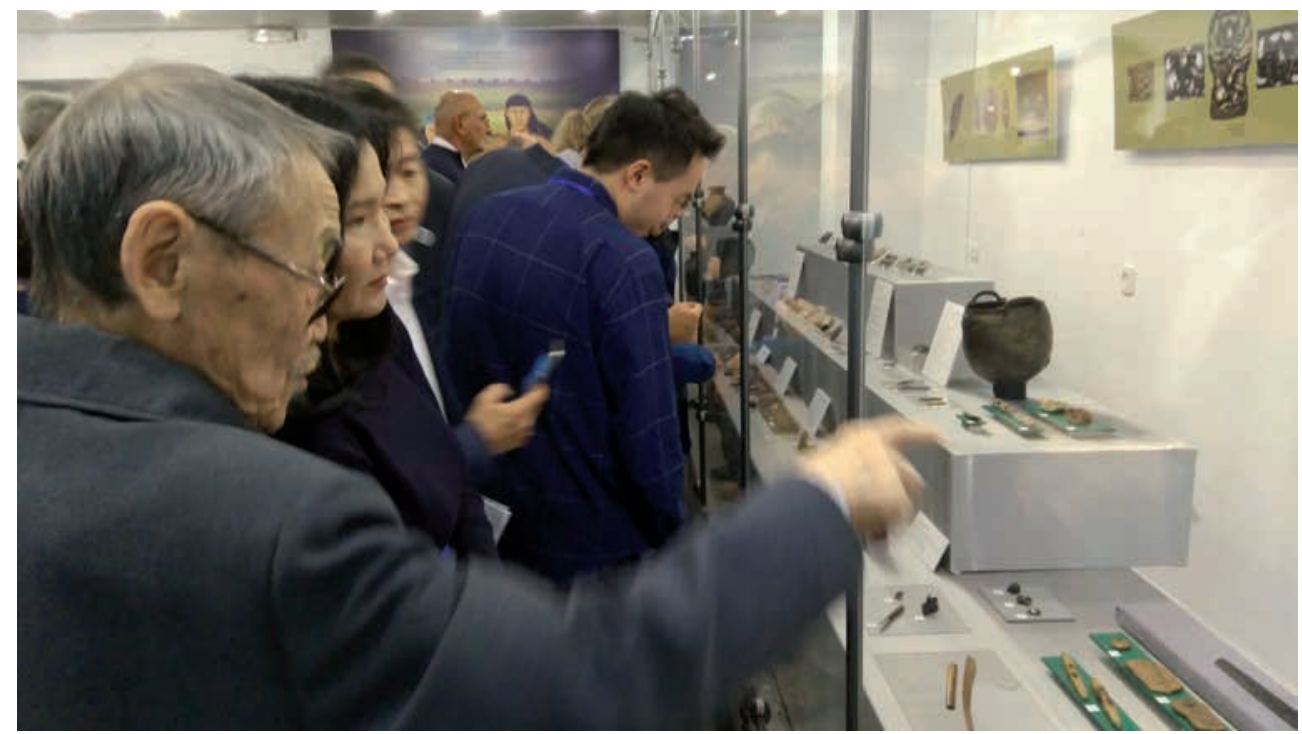

Рис. 3. На открытии выставки «Гунныл. Империя степей»

(Хунну. Тайны исчезнувших ичивилизащий). На переднем плане д.и.н. Коновалов П.Б. и министр культуры Республики Бурятия С.Б. Дагаева

Fig. 3. At the opening of the exhibition «The Huns. Empire of the Steppes "(The Xiongnu. The Secrets of the Lost Civilizations). In the foreground is a Doctor of Historical Sciences Konovalov P.B. and Minister of Culture of Buryat Republic Dagayeva S.B. 
ли секции: к.и.н. В.И. Ташак, д.и.н. А.В. Харинский), 3. «Духовная и художественная культура народов Евразии по археологическим и письменным источникам» (руководители секции: к.и.н. А.В. Варенов, д.и.н. Л.Л. Абаева), 4. «Реконструкция экономических, социально-политических процессов в кочевых империях и на их перифериях» (руководители секции: д.и.н. Л.Ф. Недашковский, д.и.н. С.А. Васютин), 5. «Трансконтинентальная коммуникация: взаимодействие и трансформация культур, идей и технологий» (руководители секции: д.и.н. И.Г. Коновалова, д.и.н. Петрова М.С.), 6. «Древняя и средневековая история Евразии в исследованиях школьников и студентов» (руководители секции: к.и.н. Н.Н. Серегин, к.и.н. Е.В. Нолев).

В рамках проведения Конгресса в Национальном музее Республики Бурятия прошло открытие масштабной выставки «Гунны. Империя степей» (Хунну. Тайны исчезнувших цивилизаций), специально приуроченной к 100-летию российской академической археологии. В торжественном мероприятии открытия выставки приняли участие министр культуры Республики Бурятия С.Б. Дагаева, директор ИМБТ СО РАН, академик РАН Б.В. Базаров, научный руководитель лаборатории археологии, этнологи и антропологии СО РАН, член-корреспондент РАН Н.Н. Крадин, а также все участники IV международного конгресса средневековой археологии евразийских степей «Кочевые империи Евразии в свете археологических и междисциплинарных исследований».

Выставка объединила богатейшие археологические коллекции хуннской культуры Национального музея Республики Бурятия, Музея Бурятского научного центра СО РАН и Кяхтинского краеведческого музея имени академика В.А. Обручева. На выставке состоялась презентация новейших археологических коллекций Лаборатории археологии, этнологии и антропологии ИМБТ СО РАН. Были представлены археологические материалы Иволгинского городища (рук. Н.Н. Крадин), неукрепленного хуннского поселения Нижний Мангиртуй (рук. Д.А. Миягашев) и нового хуннского могильника Нур-Тухум (рук. Б.А. Базаров). Среди экспонатов следует отметить фрагменты бронзовых китайских зеркал раннего и позднего типов, бронзовую пряжку с изображением кошачьего хищника, разнообразных изделий из кости и рога. Внимание экскурсантов привлекли также археологические материалы из раскопок самого большого кургана могильника Царам (рук. С.С. Миняев). На выставке были представлены детали китайской колесницы - наконечник дышла, скоба колеса, втулка, фрагменты тента (зонта). Все детали были покрыты живописными рисунками из минеральных красок. Экскурсия по выставке была проведена хранителем археологической коллекции фондов музея Л.Г. Ярославцевой. Выставка будет работать до 15 декабря 2019 г. Помимо этой выставки в дни Конгресса Музеем Бурятского научного центра СО РАН экспонировалась передвижная выставка «Средневековая торевтика в музейных коллекциях Байкальской Сибири».

По окончании секционных заседаний была организована полевая экскурсия, в ходе которой участники Конгресса посетили Иволгинский археологический комплекс и Иволгинский дацан. 
Доклады, представленные на Конгрессе, были опубликованы в сборнике научных статей «Кочевые империи Евразии в свете археологических и междисциплинарных исследований», изданном в двух книгах [Кочевые империи Евразии..., 2019а; Кочевые империи Евразии..., 2019б]. Следующий Международный конгресс средневековой археологии евразийских степей было предложено провести в Казахстане в 2021 г. на базе Института археологии им. А.Х. Маргулана, приурочив научное мероприятие к 30-летнему юбилею Института.

\section{ЛИТЕРАТУРА}

1 Кочевые империи Евразии в свете археологических и междисциплинарных исследований: сб. науч. ст. IV Международного конгресса средневековой археологии евразийских степей, посвящ. 100-летию российской академической археологии (г. Улан-Удэ, 16-21 сентября 2019 г.). В: 2 кн. / Отв. ред. Б.В. Базаров, Н.Н. Крадин. Улан-Удэ: Изд-во БНЦ СО РАН. 2019а. Кн. 1. 248 с.

2 Кочевые империи Евразии в свете археологических и междисциплинарных исследований: сб. науч. ст. IV Международного конгресса средневековой археологии евразийских степей, посвящ. 100-летию российской академической археологии (г. Улан-Удэ, 16-21 сентября 2019 г.). В: 2 кн. / Отв. ред. Б.В. Базаров, Н.Н. Крадин. Улан-Удэ: Изд-во БНЦ СО РАН. 2019б. Кн. 2. 182 с.

3 Ситдиков А.Г. Хузин Ф.Ш., Шакиров 3.Г. II Международный конгресс средневековой археологии Евразийских степей // Поволжская археология. 2012. № 2. C. 233-241.

\section{Сведения об авторах:}

Ситдиков Айрат Габитович - доктор исторических наук, членкорреспондент Академии наук Республики Татарстан, директор, Институт археологии им. А.Х. Халикова Академии наук Республики Татарстан (г. Казань, Россия); sitdikov_a@mail.ru

Базаров Биликто Александрович - научный сотрудник, отдел истории и культуры Центральной Азии, лаборатория археологии, этнологии и антропологии, Федеральное государственное бюджетное учреждение науки «Институт монголоведения, буддологии и тибетологии СО РАН» (г. Улан-Удэ, Россия); biliktobazarov@yandex.ru

Гомбожапов Александр Дмитриевич - кандидат исторических наук, ведущий научный сотрудник, координатор работы отдела истории и культуры Центральной Азии, Федеральное государственное бюджетное учреждение науки «Институт монголоведения, буддологии и тибетологии СО РАН» (г. Улан-Удэ, Россия); agombozh@gmail.com

Нолев Евгений Владимирович - кандидат исторических наук, научный сотрудник, отдел истории и культуры Центральной Азии, ученый секретарь лаборатории археологии, этнологии и антропологии, Федеральное государственное бюджетное учреждение науки «Институт монголоведения, буддологии и тибетологии CO РАН» (г. Улан-Удэ, Россия); nolev@inbox.ru

Красильников Павел Васильевич - лаборант-исследователь, отдел охранных исследований, Институт археологии им. А.Х. Халикова Академии наук Республики Татарстан (Казань, Россия); fgt888@yandex.ru 


\title{
РЕСЕЙ АКАДЕМИЯЛЫК АРХЕОЛОГИЯСЫНЫН 100 ЖЫЛДЫҒЫНА АРНАЛҒАН ЕУРАЗИЯ ДАЛАСЫНЫН ОРТАҒАСЫРЛЫҚ АРХЕОЛОГИЯСЫНЫН IV ХАЛЫҚАРАЛЫҚ КОНГРЕСІНІН ЖҰМЫСЫ ТУРАЛЫ
}

\author{
А.Г. Ситдиков, Б.А. Базаров, А.Д. Гомбожапов, \\ Е.В. Нолев, П.В. Красильников
}

2019 жылғы 16-21 қыркүйек күндері Улан-Удэ қаласында Ресей академиялық археологиясының 100 жылдығына арналған «Еуразияның көшпелі империялары археологиялық және пәнаралық зерттеулер жарияланымдарында» атты Еуразия даласының ортағасырлық археологиясының IV халықаралық конгресі өтті. Конгреске қатысу үшін Ресей, Қазақстан, Франция, Германия, Австрия, Ұлы Британия, Канада, Швейцария, Испания, Болгария, Венгрия, Хорватия, Украина, Түркия, Израил, Үндістан, Қырғызстан, Қытай, Жапония және Моңғолия секілді елдерден 229 баяндамашы өтінім білдірген. Конгресс аясында Бурят Республикасының Ұлттық музейінде «Ғұндар. Дала империялары» (Хундар. Жоғалған өркениеттер құпиялары) тақырыбындағы көрме ашылды. Сондай-ақ конгресс барысында алдыңғы жүзжылдықта қалыптасқан академиялық археология ғылымының тәжірибиесіне арқа сүйей дамып отырған заманауи археологияның жетістіктері көрсетілді және алдағы уақыттағы мақсаты мен міндеттері айтылды. Келесі Еуразия даласының ортағасырлық археологиясының халықаралық конгресі 2021 жылы Ә.Х. Марғұлан атындағы Археология институтының 30 жылдық мерейтойын өткізуге орайластырылып Қазақстанда ұйымдастырылады.

Түйін сөздер: археология, халықаралық конгресс, Еуразия, көшпелі империялар, қала мәдениеті, пәнаралық зерттеулер

\section{ON THE IV INTERNATIONAL CONGRESS OF MEDIEVAL ARCHAEOLOGY OF THE EURASIAN STEPPES, DEDICATED TO THE 100TH ANNIVERSARY OF THE RUSSIAN ACADEMIC ARCHEOLOGY}

\author{
A.G. Sitdikov, B.A. Bazarov, A.D. Gombozhapov, \\ E.V. Nolev, P.V. Krasilnikov
}

The IV International Congress of Medieval Archeology of the Eurasian Steppes «Nomadic Empires of Eurasia in Archaeological and Interdisciplinary Studies», dedicated to the 100th Anniversary of the Russian Academic Archeology was held on September 16-21, 2019 in Ulan-Ude. To participate in the Congress 229 reports of the scientists from Russia, Kazakhstan, France, Germany, Austria, Great Britain, Canada, Switzerland, Spain, Bulgaria, Hungary, Croatia, Ukraine, Turkey, Israel, Kyrgyzstan, India, China, Japan and Mongolia were submitted. As part of the Congress at the National Museum of the Republic of Buryatia was the opening of the exhibition "The Huns. Empire of the Steppes" (The Xiongnu. The Secrets of the Lost Civilizations). During the Congress, the achievements of contemporary archeology and the previous century of experience were demonstrated. New promising goals and objectives in the field of academic archaeological science were set. The next International Congress of Medieval Archeology of the Eurasian Steppes will be held in Kazakhstan in 2021 on the basis of A. Kh. Margulan Institute of Archeology in celebration of the 30th anniversary of the Institute.

Keywords: archaeology, international congress, Eurasia, nomadic empires, urban culture, interdisciplinary research

\section{REFERENCES}

1 Bazarov, B. V., Kradin, N. N. (Eds.). 2019a. Kochevye imperii Evrazii v svete arkheologicheskikh i mezhdisciplinarnykh issledovanii. V 2 kn. Kn. 1. Ulan-Ude: Institute for Mongolian, Buddhist and Tibetan Studies of SB RAS Publ. (in Russian and Eng.). 
Ситдиков А.Г., Базаров Б.А., Гомбожапов А.Д., Нолев Е.В., Красильников П.В. О работе IV международного конгресса средневековой археологии евразийских степей...

2 Bazarov, B. V., Kradin, N. N. (Eds.). 2019b. Kochevye imperii Evrazii v svete arkheologicheskikh i mezhdisciplinarnykh issledovanii. V $2 \mathrm{kn}$. Kn. 2. Ulan-Ude: Institute for Mongolian, Buddhist and Tibetan Studies of SB RAS Publ. (in Russian and Eng.).

3 Sitdikov, A. G., Khuzin, F. Sh., Shakirov, Z. G. 2012. In Povolzhskaya arkheologiya, 2, 233-241 (in Russian).

About the Authors:

Sitdikov Ayrat G. Doctor of Historical Sciences, Corresponding Member of the National Academy of Sciences of the Republic of Tatarstan, Director, Institute of Archaeology named after A. Kh. Khalikov, Kazan, Russia; sitdikov_a@mail.ru

Bazarov Bilikto A. Researcher, Department of history and culture of Central Asia, Laboratory of archaeology, ethnology and anthropology, Institute for Mongolian, Buddhist and Tibetan Studies of Siberian Branch of Russian Academy of Sciences, Ulan-Ude, Russia; biliktobazarov@yandex.ru

Gombozhapov Aleksandr D. Candidate of historical sciences, Coordinator of Department of history and culture of Central Asia, Laboratory of archaeology, ethnology and anthropology, Institute for Mongolian, Buddhist and Tibetan Studies of Siberian Branch of Russian Academy of Sciences, Ulan-Ude, Russia; agombozh@gmail.com

Nolev Evgeniy V. Candidate of historical sciences, Science secretary the Laboratory of archaeology, ethnology and anthropology, Institute for Mongolian, Buddhist and Tibetan Studies of Siberian Branch of Russian Academy of Sciences, Ulan-Ude, Russia; nolev@ inbox.ru

Krasilnikov Pavel V. Laboratory researcher, Department of conservation research, Institute of Archaeology named after A. Kh. Khalikov, Kazan, Russia; fgt888@yandex.ru 